\section{Effects of protein quality on appetite and energy metabolism in normal weight subjects}

\author{
Efeitos da qualidade proteica no apetite e metabolismo \\ energético de indivíduos eutróficos
}

Rita de Cássia Gonçalves Alfenas', Josefina Bressan', Aline Cardoso de Paiva'

\begin{abstract}
Objective: The purpose of this study was to compare the effects of consumption of different protein sources on food intake and energy expenditure in normal weight subjects. Subjects and methods: Breakfast preparations (casein, soy protein, whey protein or control) were ingested during seven consecutive days. Appetite, food intake, and energy expenditure were assessed. Results: Casein consumption led to a lower energy intake than whey protein. There was lower energy intake on day 7 than on day 1 of the casein session. Soy protein preparations resulted in higher diet induced thermogenesis (DIT) than in control preparations. The respiratory quotient (RQ) obtained in the whey protein session was lower than the control and soy protein sessions. Conclusion: These results suggest that the consumption of different protein types leads to distinct effects on satiety (casein), DIT (soy protein), and/or RO (whey protein). Arq Bras Endocrinol Metab. 2010;54(1):45-51

\section{Keywords}

Appetite; food intake; energy expenditure; soy protein; whey protein; casein
\end{abstract}

\section{RESUMO}

Objetivo: O objetivo deste estudo foi comparar os efeitos do consumo de diferentes fontes proteicas na ingestão alimentar e gasto energético em indivíduos eutróficos. Sujeitos e métodos: Preparações (caseína, proteína da soja, proteína do soro de leite ou controle) foram ingeridas no desjejum, durante sete dias consecutivos. Resultados: A caseína resultou em menor ingestão calórica do que o soro de leite. Houve uma menor ingestão calórica no último dia da sessão da caseína em relação ao primeiro dia. Preparações contendo proteína da soja resultaram em maior termogênese induzida pela dieta (TID) em comparação às preparações controle. 0 cociente respiratório (CR) obtido na sessão do soro de leite foi menor que na sessão controle e da proteína da soja. Conclusão: Esses resultados sugerem que o consumo de diferentes tipos de proteínas resulta em efeitos distintos na saciedade (caseína), TID (proteína da soja) e/ou CR (proteína do soro). Arq Bras Endocrinol Metab. 2010;54(1):45-51

\section{Descritores}

Apetite; ingestão alimentar; gasto energético; proteína da soja; caseína
Departamento de Nutrição e Saúde da Universidade Federal de Viçosa (UFV), Viçosa, MG, Brasil

\section{Correspondence to:}

Rita de Cássia Gonçalves Alfenas Universidade Federal de Viçosa Departamento de Nutrição e Saúde Av. PH Rolfs, $s / n$

36570-000 - Viçosa, MG, Brasil

ralfenas@ufv.br

Received on Mar/26/2009 Accepted on Oct/14/2009

\section{INTRODUCTION}

A mong the macronutrients, protein has a higher satiety power than carbohydrate and fat $(1,2)$. This effect has been attributed to the higher thermogenic response of protein $(2,3)$. Studies involving humans suggest that different protein sources may differ in their satiating capacity $(4,5)$. However, Lang and cols. (6) did not observe any effect of protein quality on satiety.
This discrepancy could be attributed to methodological problems, which can hamper the interpretation of the results reported in these studies.

The effect of ingestion of preloads containing different types of protein (egg albumin, casein, gelatin, soy protein, pea protein or wheat gluten) on satiety and food intake was investigated (6). No effect of protein quality on 24-hour satiety or energy intake was 
observed. However, besides the fact that the subjects could freely ingest tea and coffee with the test meal, the test foods differed in macronutrient and fiber content. Considering that caffeine can stimulate both lypolysis and energy expenditure (7), the ingestion of caffeinated drinks must be controlled in such studies. The differences in terms of macronutrients also compromise the interpretation of the results (8).

A higher satiety was observed after the ingestion of fish, compared to beef and chicken. However, 24-hour energy intake was not evaluated (9). It was shown that short-term evaluation of meal response may not predict its effect on satiety and, consequently, caloric ingestion in the following 24 hours (10). Such fact indicates the need to conduct long-term interventional studies to evaluate the effect of protein sources on energy balance.

The results of some studies indicate that the higher thermogenic effect attributed to proteins can be mediated by the increase in protein synthesis and in ATP consumption for peptide bond synthesis, as well as by the increase in protein turnover associated with a higher ingestion of this macronutrient $(11,12)$. In a study involving 12 overweight men, it was observed that a pork diet ingestion resulted in greater energy expenditure as compared to a soy diet ingestion (13). The result of this study suggests that the protein's effect on thermogenesis might be related to the biological value of the ingested protein.

Considering the possible effects of protein quality on obesity prevention, the present study aimed to evaluate the effect of consumption of different protein sources (casein, whey protein and soy protein) on appetite and energy metabolism.

\section{SUBJECTS AND METHODS}

Since protein satiating effect may vary according to habitual protein intake (8), recruited individuals had an habitual protein intake ranging from $10 \%$ to $15 \%$ of their daily energy intake. The subjects presented mean fasting glycemia of $85.2 \pm 18.26 \mathrm{mg} / \mathrm{dL}$ and mean triglyceride concentration of $108.6 \pm 56.41 \mathrm{mg} / \mathrm{dL}$, which were assessed by capillary finger-stick blood samples (Accutrend GCT, Roche), after a 12-hour overnight fast.

The study consisted of four 7-day experimental sessions (control, whey protein, casein, and soy protein), separated by a washout period of at least 7 days. All 24 subjects participated in these first three sessions, but only 10 participated in the soy protein session. In each session, subjects randomly ingested breakfast preparations with or without the test proteins. Each subject ingested a daily portion of the preparation containing $0.5 \mathrm{~g}$ of the test protein per kilogram of body weight.

On day 1 of the first experimental session, after a 12-hour overnight fast, subjects reported to the laboratory and had their weight, height and body composition assessed. On days 1 and 7 of each experimental session, appetitive sensations were determined before, immediately after ( 0 minutes) and for 2 hours $(60$ and 120 minutes) following breakfast. On these same days, after a 12-hour overnight fast, resting energy expenditure (REE), respiratory quotient (RQ) and diet-induced thermogenesis (DIT) were measured. Following that, they were allowed to conduct their usual daily activities, keeping a free-feeding dietary record of all the food ingested. The level of physical activity conducted by the participants and their appetitive sensations were assessed during the whole study. The study protocol was approved by the Human Subjects Review Committee of the Federal University of Viçosa (MG), Brazil.

\section{Physical activity assessment}

From day 1 to 7 of each experimental session, participants maintained 24-hour physical activity logs. Physical activity data obtained were analyzed with the Nutri Quest program, version 2.1 (McGraw-Hill, Columbus, $\mathrm{OH}, \mathrm{USA})$.

\section{Test preparations}

Milk shakes (strawberry, chocolate, guava or banana flavored) with crackers and a dip, or cookies, or cake (orange or lemon flavored) were offered during the study. These preparations contained one of the test proteins (casein, or soy protein, or whey protein) or no test proteins (control session). All test preparations had their fiber content adjusted by the addition of a fiber supplement. Additional nutritional characteristics presented by the test preparations are shown in table 1 . Subjects evaluated the preparations in terms of pleasantness (taste, smell, texture and overall appearance) and taste intensity (sweet, sour, salty and bitter) using a 9-point bipolar category scale, containing expressions ranging from "poor" to "very good" (14). All preparations received scores from 7 to 9 , thus being considered palatable. There was no statistical difference in the palatability ratings between the test preparations. 
Table 1. Mean \pm SD macronutrient composition, fiber content, and calories presented by the preparations served for breakfast in the four experimental sessions of the study

\begin{tabular}{lccccc}
\hline Experimental session & Carbohydrate $\mathbf{( g )}$ & Protein $\mathbf{( g )}$ & Fat $\mathbf{( g )}$ & Fiber $(\mathbf{g})$ & Calories $(\mathbf{k c a l )}$ \\
\hline Whey protein & $30.3 \pm 6.9^{\mathrm{a}}$ & $24.2 \pm 3.9^{\mathrm{c}}$ & $5.8 \pm 2.8$ & $6.5 \pm 0$ & $262.8 \pm 17.4$ \\
Casein & $30.3 \pm 7.6^{\mathrm{a}}$ & $25.6 \pm 5.7^{\mathrm{c}}$ & $5.9 \pm 2.6$ & $6.5 \pm 0$ & $266.4 \pm 23.9$ \\
Soy protein & $30.5 \pm 9.1^{\mathrm{a}}$ & $24.3 \pm 4.5^{\mathrm{c}}$ & $6.1 \pm 2.5$ & $6.5 \pm 0$ & $267.0 \pm 28.9$ \\
Control & $45.5 \pm 6.9^{\mathrm{b}}$ & $8.5 \pm 4.6^{\mathrm{d}}$ & $5.7 \pm 2.5$ & $6.5 \pm 0$ & $267.3 \pm 17.9$ \\
\hline
\end{tabular}

Values in each column followed by different letters are significantly different from each other $(p=0.05(a, b)$, and $p=0.01(c, d))$ (Kruskal-Wallis test).

\section{Rest energy expenditure and diet induced thermogenesis assessments}

Participants were instructed to avoid alcohol consumption and to refrain from heavy physical activity on the day preceding the tests. On days 1 and 7 of each experimental session, subjects reported to the laboratory after a 12-hour overnight fast. Following the anthropometric and body composition assessments, subjects rested in a quiet and dark room in supine position for 30 minutes before the test began. REE was assessed during the next 30 minutes. Following that, subjects ingested the test preparation within 15 minutes. DIT was measured for 60 minutes.

REE and DIT were assessed in the supine position through indirect calorimetry (Deltatrac $\mathrm{II}^{\circledR}$ Datex, Finland). The respiratory quotient (RQ) was calculated as $\mathrm{CO}_{2}$ produced $/ \mathrm{O}_{2}$ consumed. $\mathrm{RQ}$ was converted into kilocalories of heat produced per body surface area per hour and extrapolated to total energy expenditure (TEE) $(15,16)$.

\section{Food intake and appetitive ratings assessments}

In the first visit to the laboratory, participants were oriented to keep free-feeding dietary records. Plastic food models were used for estimations of portion size. Three-day food records (two non-consecutive weekdays and one weekend day) were recorded at baseline. Food intake on days 1 and 7 of each study session was evaluated through the analysis of dietary records containing all the foods ingested over 24-hours after test preparation consumption. Each dietary record was reviewed with the participant to ensure accuracy and completeness. Food records were evaluated using country specific nutrient databases.

Subjective appetitive ratings of hunger, fullness, desire to eat, and prospective consumption were obtained using the Satiety Labeled Intensity Magnitude Scale test (17). Participants completed the appetitive rating questionnaire immediately before and at 0 (immediately after the meal), 60 and 120 minutes after breakfast (throughout the study), lunch and dinner (on days 1 and 7 of each study session) consumption.

\section{Appetite ratings}

Appetite was assessed by ratings of hunger, desire to eat, and fullness at stipulated times (18). Food pleasantness was rated after initial tasting. All ratings were made on general labeled magnitude scales $(5,8)$.

\section{Statistical analyses}

Statistical analyses were conducted using the SPSS software (SPSS Inc, Chicago, IL), version 11.5. Descriptive statistics are presented in mean \pm standard error unless it was otherwise indicated. The statistical significance criterion adopted was $p<0.05$. Analyses of the data obtained on days 1 and 7 of each session were performed by the Wilcoxon test, while comparisons among sessions were performed by the Mann-Whitney test. The data obtained daily at each session were evaluated by analysis of variance (ANOVA) for variables with a normal distribution and the Kruskal-Wallis test for those not presenting a normal distribution.

\section{RESULTS}

Twenty-six subjects ( 13 men and 13 women), aged $23.5 \pm 3.95$ years, with a mean body mass index (BMI) of $20.5 \pm 1.46 \mathrm{~kg} / \mathrm{m}^{2}(19)$, a mean body fat of $18.41 \pm$ $8.02 \%$ (measured by tetra polar bioelectrical impedance analysis, model TBF-300, Tanita), and dietary restraint $\leq 14$ (20) were recruited for the study.

Baseline carbohydrate, fat and energy intake did not differ $(p \geq 0.33)$ from that observed in the experimental sessions. Protein intake did not differ between baseline and control sessions $(\mathrm{p}=0.35)$ or among the whey protein, casein and soy protein sessions $(\mathrm{p} \geq 0.38)$. However, the consumption of this macronutrient in these sessions was higher $(\mathrm{p}<0.001)$ as compared to the baseline and control sessions (Table 2 ). 
Body composition was not affected among the experimental sessions. The increase in protein ingestion during the study did not reduce energy intake compared to baseline (Table 3). Participants maintained their level of physical activities constant during the study.

A reduction in fullness (soy protein session) and in prospective consumption (control session) ratings was observed between days 1 and 7 of the study. However, food intake was not affected during these two sessions. The consumption of casein-based preparation led to a lower $(\mathrm{p}=0.021)$ daily energy intake than whey protein-based preparations (Figure 1A). Moreover, there was a reduction $(\mathrm{p}=0.022)$ in energy intake on day 7 compared to day $\mathrm{l}$ of the casein session (Figure 1B).

There was a higher $(\mathrm{p} \leq 0.035)$ DIT for the soy protein session than for the control session on days 1 and 7 . The DIT achieved for the soy protein session was higher $(\mathrm{p}=0.024)$ than the whey protein session on day 7 (Figure 2). The RQ verified for the whey protein session was lower than that observed for the control $(\mathrm{p} \leq$ $0.030)$ (Figure $3 \mathrm{~A}$ ) and soy protein $(\mathrm{p} \leq 0.027)$ sessions (Figure $3 \mathrm{~B}$ ) on days $\mathrm{l}$ and 7 . The consumption of whey protein led to a lower $(\mathrm{p}=0.015) \mathrm{RQ}$ than the one observed on day 7 of the control session (Figure 3A).

\section{DISCUSSION}

In the present study, the mean protein ingestion increased from approximately $1.4 \mathrm{~g}$ of protein per kilogram of body weight or $14.9 \%$ of kcal/day (at baseline) to $1.9 \mathrm{~g} / \mathrm{kg}$ or $18.3 \%$ of $\mathrm{kcal} /$ day (during the study). However, this protein intake increase was not sufficient to cause a reduction in energy intake. Nevertheless, It should be noted that the protein intake in this study was lower than that observed in another study $(18,21-23)$ in which a reduction in food intake was observed.

A reduction in fullness and in prospective consumption ratings was observed in the soy protein and control sessions, respectively. However, daily energy intake was not affected in those sessions. These results indicate that subjective appetitive ratings may not be a good proxy measure of food intake (24-26). Thus, a subjective evaluation of appetite may be considered as a method less precise than a direct evaluation of food intake to determine energy balance.

In another study (27), whey consumption resulted in a lower desire to eat and higher fullness sensation than casein consumption. However, while in the other study (27) desire to eat and fullness were evaluated based on satiety-related hormones (cholecystokinin

Table 2. Mean \pm SD macronutrient and energy intake during the 7 days of the study at baseline and on each experimental session

\begin{tabular}{lccccc}
\hline & $\begin{array}{c}\text { Baseline } \\
(\mathbf{n = 2 4 )}\end{array}$ & $\begin{array}{c}\text { Control } \\
(\mathbf{n = 2 4 )}\end{array}$ & $\begin{array}{c}\text { Whey protein } \\
(\mathbf{n = 2 4 )}\end{array}$ & $\begin{array}{c}\text { Casein } \\
(\mathbf{n = 2 4 )}\end{array}$ & $\begin{array}{c}\text { Soy protein } \\
(\mathbf{n}=\mathbf{1 0})\end{array}$ \\
\hline Carbohydrate $(\mathrm{g})$ & $322.1 \pm 92.1$ & $379.3 \pm 129.2$ & $350.3 \pm 106.3$ & $366.3 \pm 92.4$ & $353.0 \pm 78.6$ \\
Protein $(\mathrm{g})$ & $81.8 \pm 16.3^{\mathrm{a}}$ & $91.2 \pm 29.3^{\mathrm{ab}}$ & $108.9 \pm 24.4^{\mathrm{b}}$ & $115.5 \pm 24.4^{\mathrm{b}}$ & $108.7 \pm 24.4^{\mathrm{b}}$ \\
Fat (g) & $69.8 \pm 19.1$ & $68.9 \pm 17.9$ & $63.5 \pm 15.2$ & $75.0 \pm 34.5$ & $79.8 \pm 26.1$ \\
Energy (kcal) & $2193.6 \pm 563.8$ & $2369.6 \pm 620.9$ & $2557.1 \pm 588.3$ & $2471.3 \pm 803.4$ & $2572.9 \pm 576.3$ \\
\hline
\end{tabular}

Kruskal-Wallis test.

Lines followed by the same letter are not significantly $(p \geq 0.33)$ different from each other.

Lines followed by different letters are significantly different $(p<0.001)$ from each other.

Table 3. Mean \pm SD energy intake, body weight and body fat presented by the subjects on day 1 and day 7 of each experimental session

\begin{tabular}{lccccc}
\hline & & $\begin{array}{c}\text { Control } \\
(\mathbf{n = 2 4 )}\end{array}$ & $\begin{array}{c}\text { Whey protein } \\
(\mathbf{n = 2 4 )}\end{array}$ & $\begin{array}{c}\text { Casein } \\
(\mathbf{n = 2 4 )}\end{array}$ & $\begin{array}{c}\text { Soy protein } \\
(\mathbf{n = 1 0})\end{array}$ \\
\hline Energy intake (kcal/day) & Day 1 & $2431 \pm 833$ & $2973 \pm 930$ & $2485 \pm 685$ & $2624 \pm 796$ \\
& Day 7 & $2344 \pm 779$ & $2344 \pm 979$ & $2185 \pm 573$ & $2496 \pm 592$ \\
Body weight (kg) & Day 1 & $58.4 \pm 7.8$ & $59.1 \pm 7.6$ & $59.2 \pm 7.9$ & $58.4 \pm 7.6$ \\
& Day 7 & $58.4 \pm 7.9$ & $59.3 \pm 7.5$ & $59.3 \pm 7.9$ & $58.7 \pm 7.4$ \\
Body fat (\%) & Day 1 & $17.6 \pm 8.7$ & $18.4 \pm 8.0$ & $17.7 \pm 7.8$ & $16.8 \pm 6.3$ \\
& Day 7 & $17.3 \pm 8.3$ & $18.7 \pm 8.5$ & $18.5 \pm 8.0$ & $18.6 \pm 7.6$ \\
\hline
\end{tabular}

Values obtained on day 1 and day 7 are not significantly different $(p \geq 0.234)$ from each other (Wilcoxon test). 
A

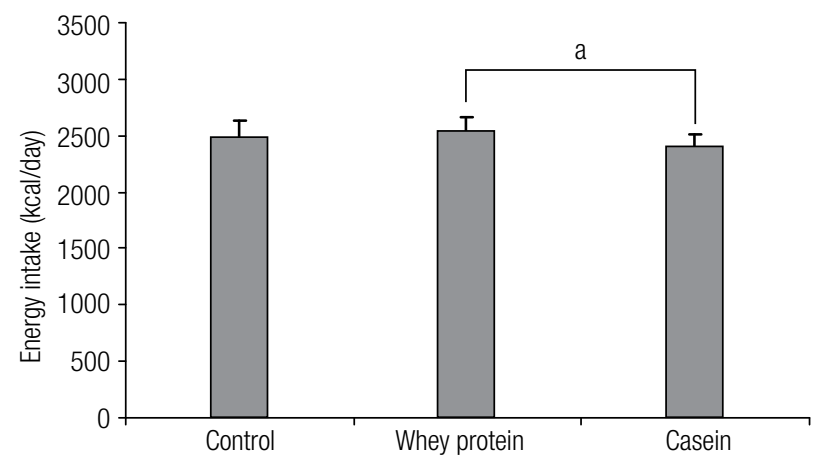

B

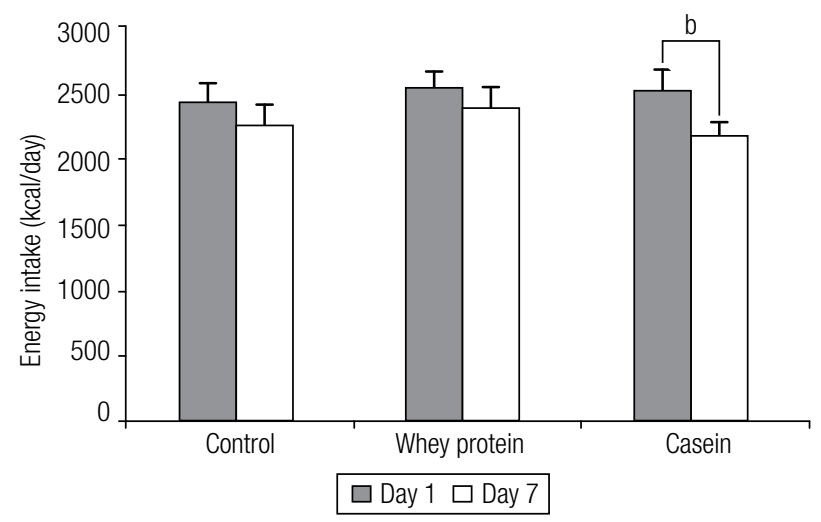

Figure 1. Mean energy intake ( $k c a l / d a y)(n=26) \pm S E$ associated with the consumption of preparations containing one of the test proteins (whey protein, casein, soy protein) or without any of the test proteins (control session) for breakfast, during 7 consecutive days (A) (Mann-Whitney test), and on day 1 and day 7 of each study session (B) (Wilcoxon test). Values indicated above differ significantly from each other ( $\left({ }^{\mathrm{a}} p=0.021\right.$; ${ }^{\mathrm{b}} \mathrm{p}=0.022$ ).

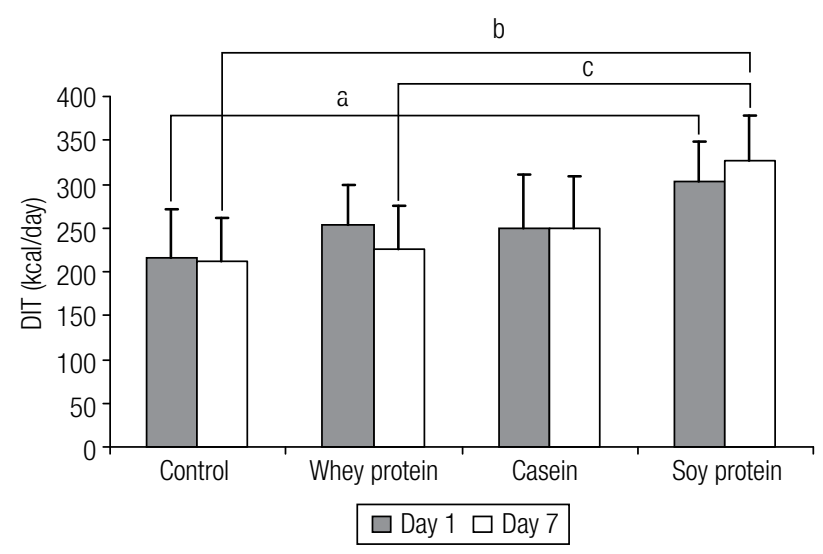

Figure 2. Mean diet induced thermogenesis $(\mathrm{DIT}) \pm \mathrm{SE}(\mathrm{n}=10)$ obtained on days 1 and 7 of the study sessions (Wilcoxon test). Test preparations containing one of the test proteins (whey protein, casein, soy protein sessions) or without any of the test proteins (control session) were ingested for 7 consecutive days. Values indicated above differ significantly from each other $\left({ }^{a} p=0.015 ;{ }^{b} p=0.035 ;{ }^{c} p=0.024\right)$.
A

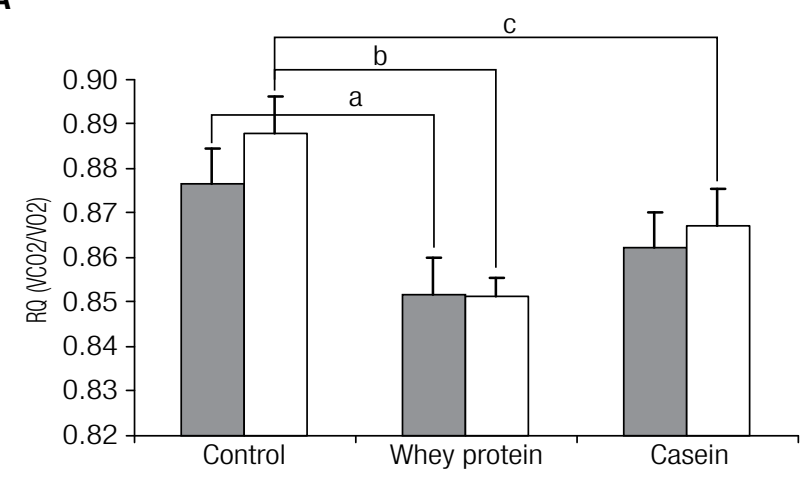

B

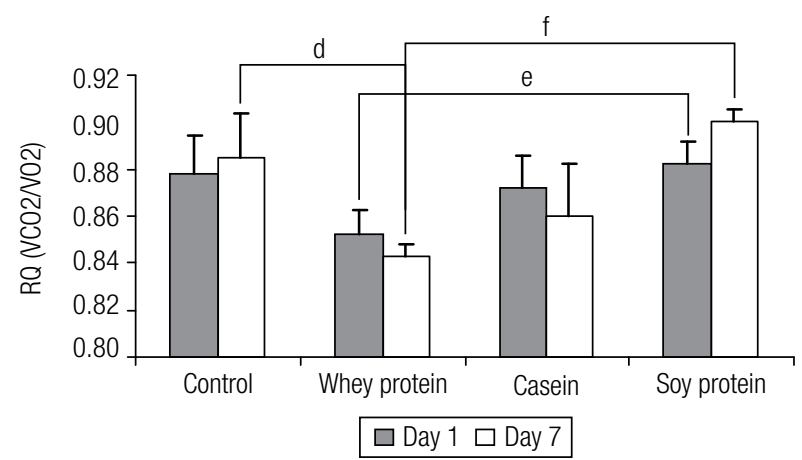

Figure 3. Mean respiratory quotient $(R Q) \pm S E$ presented by the subjects who participated in $3(n=26)(A)$ or $4(n=10)$ (B) study sessions. Test preparations containing one of the test proteins (whey protein, casein, soy protein sessions) or without any of the test proteins (control session) were ingested for 7 consecutive days. The values indicated above differed significantly from each other $\left({ }^{\mathrm{a}} p=0.030 ;{ }^{\mathrm{b}} p=0.000 ;{ }^{\mathrm{c}} p=0.015\right.$; ${ }^{\mathrm{d}} p=0.031 ;{ }^{\mathrm{e}} \mathrm{p}=0.008 ;{ }^{\mathrm{f}} \mathrm{p}=0.027$ ).

and GLP-1), our study used questionnaires to evaluate appetitive sensations. Alterations in hormone levels might be more sensitive to detect changes in appetite sensations than the questionnaires applied in the present study.

In the present study, the consumption of casein for 7 consecutive days led to a lower daily energy intake than whey protein. Moreover, there was a reduction in caloric intake on day 7 as compared to day 1 of the casein session. The stronger reduction in food intake of casein may be attributed to its slower gastric emptying rate in comparison to whey protein (28). According to some authors $(27,29)$, a delay in gastric emptying can favor increased satiety. However, in another study (4) there was a lower energy intake 90 minutes after the consumption of whey protein compared to casein. Some authors point out that a short-term food 
response evaluation may not predict satiety effects and consequently, energy intake in the following 24 hours (10). Therefore, the difference in the results of these two studies might be due to the period of time in which this type of response was assessed.

A higher DIT was observed during the soy protein session as compared to the control session (higher carbohydrate content) in this study. In another study (30) it was also observed that consumption of soy protein hydrolysate induced a higher DIT than that observed after consumption of a high carbohydrate load. Such result was attributed to higher glucagon secretion in response to a soy protein hydrolysate load, which causes an increase in post-prandial thermogenesis. The higher content of branched amino acids in soy protein compared to whey protein may also have affected DIT in this study. Higher levels of branched amino acids are good predictors of glucagon secretion (30).

The consumption of whey protein-based preparations led to lower RQ than the control and soy protein preparations. This result suggests that the consumption of whey protein might favor a higher increase in fat lipid oxidation (31) and a lower risk of weight gain (32). Despite the changes detected in DIT and RQ, no difference in total energy expenditure was detected in the four treatments applied in this study. Further studies are necessary to evaluate long-term effects of protein quality on body weight and body composition in humans.

\section{CONCLUSIONS}

A daily consumption of approximately $2 \mathrm{~g}$ of protein per kilogram of body weight for seven consecutive days was not sufficient to cause a reduction in energy intake as compared to the consumption of $1.4 \mathrm{~g} / \mathrm{kg}$. However, besides leading to a reduction in energy intake on the last day in relation to the first day of casein session, casein consumption led to a lower daily energy intake than whey protein. Thus, casein presented a stronger satiety power than whey protein. Due to its higher TID, soy protein may have an important effect on postprandial energy expenditure compared to whey protein and control preparations. The lower RQ obtained in response to the whey protein consumption compared to the soy protein and the control preparations suggests that whey protein consumption may favor body weight and body fat control.

Acknowledgments: this study was supported by grants from the Brazilian government organization CNPq (Conselho Nacional de Desenvolvimento Científico e Tecnológico). Thanks to Jeffrey Ryan Oar from Oregon State University for the English revision of this article.

Disclosure: no potential conflict of interest relevant to this article was reported.

\section{REFERENCES}

1. Jequier E. Pathways to obesity. Int J Obes Relat Metab Disord. 2002;26(2):S12-7.

2. Paddon-Jones D, Westman E, Mattes RD, Wolfe RR, Astrup A, Westerterp-Plantenga M. Protein, weight management, and satiety. Am J Clin Nutr. 2008;87(5):1558S-1561S.

3. Westerterp-Plantenga MS. Protein intake and energy balance. Regul Pept. 2008;149(1-3):67-9.

4. Hall WL, Millward SJL, Morgan LM. Casein and whey exert different effects on plasma amino acid profiles, gastrointestinal hormone secretion and appetite. Br J Nutr. 2003;89:239-48.

5. Luhovyy BL, Akhavan T, Anderson GH. Whey proteins in the regulation of food intake and satiety. J Am Coll Nutr. 2007;26(6):704S-12S.

6. Lang V, Bellisle F, Oppert JM, Craplet C, Bornet FRJ Slama G. Satiating effect of proteins in healthy subjects: a comparison of egg albumin, casein, gelatin, soy protein, pea protein, and wheat gluten. Am J Clin Nutr. 1998;67:1197-204.

7. Acheson KJ, Gremaud G, Meirim I, Montigon F, Krebs Y, Fay LB, et al. Metabolic effects of caffeine in humans: lipid oxidation or futile cycling? Am J Clin Nutr. 2004;79(1):40-6.

8. Long SJ, Jeffcoat AR, Millward DJ. Effect of habitual dietary-protein intake on appetite and satiety. Appetite. 2000;35:79-88.

9. Uhe AM, Collier GR, O'Dea K. A comparison of the effects of beef, chicken and fish protein on satiety and amino acid profiles in lean male subjects. J Nutr. 1992;122:467-72.

10. Holt SHA, Miller BJ. Increased insulin response to ingested foods are associated with lessened satiety. Appetite. 1995;24:43-54.

11. Garlick PJ, Mcnurlan MA, Ballmer PE. Influence of dietary protein intake on whole-body protein turnover in humans. Diabetes Care. 1991;14:1189-98.

12. Giordano M, Castellino P. Correlation between amino acid induced changes in energy expenditure and protein metabolism in humans. Nutrition. 1997;13:309-12.

13. Mikkelsen PB, Toubro S, Astrup A. Effect of fat-reduced on 24-h energy expenditure: comparisons between animal protein, vegetable protein and carbohydrate. Am J Clin Nutr. 2000;72:1135-41.

14. Merril EP, Kramer FM, Cardello A, Schutz H. A comparison of satiety measures. Appetite. 2002;39:181-3.

15. Buscemi S, Caimi G, Verga S. Resting metabolic rate and postabsorptive substrate oxidation in morbidly obese subjects before and after massive weight loss. Int J Obes. 1996;20(1):41-6.

16. Valtueña S, Salas-Salvadó J, Lorda PG. The respiratory quotient as a prognostic factor in weight-loss rebound. Int $\mathrm{J}$ Obes. 1997;21(9):811-7.

17. Cardello AV, Schutz HG, Lesher LI, Merrill E. Development and testing of a labeled magnitude scale of satiety. Appetite. 2005;44:1-13.

18. Lejeune MP, Kovacs EM, Westerterp-Plantenga MS. Additional protein intake limits weight regain after weight loss in humans. Br J Nutr. 2005;93:281-9.

19. World Health Organization. Defining the problem of overweight and obesity. In: World Health Organization. Obesity: preventing and managing the global epidemic: report of a Who Consultation. Geneva; 2000. p. 241-3. (WHOTechnical Report Series, 894). 
20. Strunkard AJ, Messick S. The three factor eating questionnaire to measure dietary restraint, desinhibition, and hunger. J Psychosom Res. 1985;29:71-83.

21. Farnsworth E, Luscombe ND, Noakes M, Wittert, Argyiou E, Clifton PM. Effect of high-protein, energy-restricted control, and lipid concentration in overweight and hyperinsulinemic men and women. Am J Clin Nutr. 2003;78;31-9.

22. Skov AR, Toubro S, Ronn B, Holm L, Astrup A. Randomized trial on protein vs carbohydrate in ad libitum fat reduced diet for treatment of obesity. Int J Obes Relat Metab Disord. 1999;23:528-36.

23. Weigle DS, Breen PA, Matthys CC, Callahan HS, Meeuws KE, Burden VR, et al. A high-protein diet induces sustained reductions in appetite, ad libitum caloric intake, and body weight despite compensatory changes in diurnal plasma leptin and ghrelin concentrations. Am J Clin Nutr. 2005;82:41-8.

24. Ball SD, Keller KR, Moyer-Mileur LH, Ding Y, Donaldson D, Jackson D. Prolongation of satiety after low versus moderately high glycemic index meals in obese adolescents. Pediatrics. 2003;111:488-94.

25. Bartoshuk LM, Duffy VB, Green BC, Hoffman HJ, KO CW, Lucchina LA. Valid across-group comparisons with labeled scales: the gLMS versus magnitude matching. Physiol Behav. 2004;82:109-11.

26. Stubbs RJ, Hughes DA, Johnstone AM, Rowley E, Reid C, Elia M, et al.The use of visual analogue scales to assess motivation to eat in human subjects: a review of their reliability and validity with an evaluation of new hand-held computerized systems for temporal tracking of appetite ratings. Br J Nutr. 2000;84(4):405-15.

27. Capasso R, Izzo AA. Gastrointestinal regulation of food intake: general aspects and focus on anandamide and oleoylethanolamide. J Neuroendocrinol. 2008;20 Suppl 1:39-46.

28. Fox M, Georgi G, Boehm G, Menne D, Fried M,Thumshirn M. Dietary protein precipitation properties have effects on gastric emptying in healthy volunteers. Clin Nutr. 2004;23(4):641-6.

29. Gallagher TK, Geoghegan JG, Baird AW, Winter DC. Implications of altered gastrointestinal motility in obesity. Obes Surg. 2007;17(10):1399-407.

30. Claessens $M$, Calame W, Siemensma AD, Saris WH, van Baak $M A$. The thermogenic and metabolic effects of protein hydrolysate with or without a carbohydrate load in healthy male subjects. Metabolism. 2007;56(8):1051-9.

31. Melanson EL, Donahoo WT, Grunwald GK, Schwartz R. Changes in 24-h substrate oxidation in older and younger men in response to exercise. J Appl Physiol. 2007;103(5):1576-82.

32. Filozof CM, Murúa C, Sanchez MP, Brailovsky C, Perman M, Gonzalez $\mathrm{C}$, et al. Low plasma leptin concentration and low rates of fat oxidation in weight-stable postobese subjects. Obes Res. 2000;8(3):205-10. 